DOI: https://doi.org/10.32838/2523-4803/70-4-8

УДК 316.472(477):339.923

\title{
Довганик Н.М.
}

кандидат історичних наук,

доцент кафедри політичних технологій,

ДВНЗ «Київський національний економічний

університет імені Вадима Гетьмана»

Чалюк Ю.О.

кандидат економічних наук,

доцент кафедри соціологіі,

ДВНЗ «Київський національний економічний

університет імені Вадима Гетьмана»

\section{Dovhanyk Nadiia, Chaliuk Yuliia}

Kyiv National Economic University named after Vadym Hetman

\section{ТИПОЛОГІЗАЦІЯ РЕФОРМ МІСЦЕВОГО САМОВРЯДУВАННЯ}

Світ вступив в епоху глобальної соціально-економічної кризи, якої за масштабами, глибиною $i$ тривалістю не було після Великої депресії. Пандемія як зовнішній шок паралізувала економіку провідних держав, сприяла їхній добровільній самоізоляиії. У сучасних кризових умовах, коли закриваються кордони, розірвані господарські зв'язки, відсутнє регулярне сполучення на міжнародному, регіональному та національному рівнях, закономірно зростає роль місиевих органів влади та їхня відповідальність за розв'язання проблем самоврядування. Криза стає каталізатором прочесів децентралізачії та трансформації діяльності місиевих органів влади. Ці фактори і зумовлюють актуальність вибраної теми, необхідність дослідження світової практики децентралізації та здійснення типологізаціі муніципальних реформ. Використання методів історико-логічного і структурно-факторного аналізу дало змогу ідентифікувати організаційні, фінансові, функціонально-прочедурні реформи органів місцеевої влади та коригування кількості територіальних громад.

Ключові слова: місиеве самоврядування, типологізація муніципальних реформ, європейська практика децентралізації, територіальні громади, місцева автономія. 
Постановка проблеми. Світовий досвід показує, що всі демократичні нації намагаються забезпечити право на місцеве самоврядування за умови повноцінного виконання центральним урядом обов'язків загальнодержавного характеру та реалізації ним захисту прав усіх громадян. Проте у практичній діяльності місцеві органи самоврядування стикаються, як відомо, 3 низкою організаційних, фінансових та інших проблем. Це зумовлює потребу в реформах місцевого самоврядування, які здебільшого стосуються структури органів, їхніх функцій, відносин із центральними органами влади та між різними рівнями управління на місцях [1]. Але різними також є й особливості країн, де здійснюються реформи, їхні державні устрої, традиції тощо. Крім того, мотивація реформування може лежати в різних площинах, де превалюють економічні, соціальні, демографічні та інші фактори. Враховуючи все це, реформи місцевого самоврядування можна поділити на чотири типи: коригування кількості одиниць, організаційні, фінансові та функціональні реформи.

Аналіз останніх досліджень і публікацій. Значний внесок у дослідження проблем децентралізації та трансформації діяльності місцевих органів влади зробили такі науковці-теоретики і вчені-практики, як О.В. Батанов, В.М. Вакуленко, П.В. Ворона, В.Б. Гройсман, Ю.Г. Іванченко, В.В. Кравченко, А.П. Лелеченко, В.М. Литвин, Р.М. Плющ, М.О. Пухтинський та інші. Однак проблемою нині $є$ відсутність класифікації муніципальних реформ через недостатнє вивчення й узагальнення європейського досвіду децентралізації. Ще й досі не здійснено офіційного перекладу установчих договорів СС українською мовою та не вироблено єдиного державного стандарту, до якого повинно бути приведене українське законодавство, щоб відповідати нормам права Свросоюзу.

Формулювання цілей статті. Метою статті $\epsilon$, по-перше, наукове дослідження зарубіжної практики процесів децентралізації, по-друге, ідентифікація особливостей та закономірностей розвитку муніципального руху в країнах Свропейського Союзу і, по-третє, на основі цього узагальненого досвіду - здійснення типологізації реформ місцевого самоврядування.

Виклад основного матеріалу. Реформи коригування кількості одиниць почали здійснювати в зарубіжних країнах після Другої світової війни і дотепер проводять у двох напрямах. Передусім вони спрямовані на зміцнення муніципалітетів через зменшення їх кількості у процесі злиття [2; 3]. Найбільшого поширення ці реформи набули в скандинавських країнах. Якщо у Швеції, наприклад, до реформи 1952 року налічувалося 2498 муніципалітетів (у найменших іноді мешкало до 150 осіб), то вже після першого об'єднання їхня кількість зменшилася до 1037 одиниць.

Другим важливим етапом у зазначеному процесі стала реформа 1962 р. (на основі закону 1961 р.). Було вирішено встановити мінімальну кількість мешканців на території однієї комуни - 8000 чоловік. За участі регіональних органів управління, що дали пропозиції для злиття низових одиниць, були створені спеціальні спільні перехідні органи, виділені відповідні кошти на об'єднання. Ці кошти йшли також і на зменшення податкового тягаря на перехідний період. Як наслідок, відбулося подальше швидке зменшення кількості низових одиниць. Наприкінці цієї реформи (1974р.) було визначено остаточну їх цифру - 279 муніципалітетів.

Слід, однак, зазначити, що під час об’єднання муніципалітетів не завжди використовувався принцип добровільності. Нерідко злиття здійснювалося під тиском центральної влади, всупереч протестам відповідних муніципальних одиниць. Це призвело до того, що деякі об'єднані муніципалітети через гострі конфлікти просто розпалися. Радикальними також були реформи місцевого самоврядування 1970 р. у Данії та 1977 р. у Бельгіï [4].

Іншим типом реформ місцевого самоврядування можна вважати організаційні реформи, метою яких була зміна внутрішньої структури територіальних одиниць. Вони насамперед були спрямовані на експериментування 3 новими організаційними формами муніципального управління. Серед подібних знахідок найвідоміші так звані вільні комуни. Програми створення вільних комун також мають скандинавську «прописку». Їх основна ідея полягала у тому, щоб запропонувати окремій групі муніципалітетів представити свої міркування щодо нових організаційних форм і звернутися за субсидіями для розроблення та втілення в життя своїх проектів. Була поставлена грандіозна мета: децентралізувати управління, оптимізувати використання ресурсів, добитися рішень, які би значною мірою відповідали місцевим потребам, поліпшити координацію, підвищити рівень ефективності, підняти ступінь впливу громадян і удосконалити місцеву демократію. Остаточним підсумком організаційних експериментів стало створення муніципальних законів, які відкривали можливості для ширшої місцевої автономії. Це насамперед стосується норвезького закону про муніципальне управління [5, с. 218-231].

Поряд із зазначеними експерименти проводилися також і у Данії - в основному щодо нових форм участі в місцевому управлінні. У Данії була здійснена спроба втілення у життя іншої організаційної форми: щоби громадяни поставали не як мешканці муніципалітету взагалі, а як споживачі муніципальних послуг (школи, дитячі садки тощо) [5, с. 245-247]. Така форма участі у громадському житті має як позитивні, так і негативні риси. Її вадою є те, що люди позбавлені можливості брати участь в управлінні як громадяни, тобто не беруть участі в усіх справах муніципалітету. Але позитивним $\epsilon$ факт, що люди, які зазвичай взагалі віддавали перевагу пасивному спогляданню, отримують можливість впливати на перебіг подій i, можливо, з часом розвинули би смак до більш зрілих форм суспільної участі.

Крім подібних експериментувань, до цього типу реформ можна віднести і здійснення заходів щодо посилення ролі мерів і рад; надання процесові при- 
йняття рішень публічного і демократичного характеру; розширення участі громадськості у прийнятті суспільно важливих рішень; запровадження обов'язкових раціональних методів планування; зміни у складі персоналу місцевих органів влади та запровадження нових правил їхньої діяльності.

Фінансові реформи, як правило, включали збільшення обсягів ресурсів, що їх центр надає органам місцевої влади, зокрема, для розрахунків за соціальними програмами, ініціатором яких він був. Спонукальний момент пояснюється бажанням центральної влади ширше залучити органи місцевого самоврядування до участі у загальнодержавних проектах. Були здійснені спроби зміцнити органи місцевої влади завдяки допуску до збирання податків або забезпечення себе іншими, альтернативними засобами фінансування, такими як: плата за послуги, прибутки з підприємств, надання послуг на ринкових засадах. Інший шлях упровадження ринкових механізмів у сферу муніципальних послуг грунтувався на ідеї ваучерів. Замість того, щоби прикріплювати жителів певної території до конкретних шкіл, лікарень, людям видавали ваучери, які давали змогу оплачувати послуги тільки тих закладів, де рівень обслуговування найбільшою мірою відповідав їхнім потребам. Таким чином, ідею сумно відомих для нас ваучерів Швеція успішно використала як ефективний ринковий механізм у сфері муніципальних послуг [5, с. 451-462].

I, нарешті, функціональні $і$ прочедурні реформи включають комплекс різноманітних змін, які ще більше розмежували обов'язки і права місцевої та центральної влади. У деяких країнах - Франції, Італії, Іспанії контрольні функції префектів були послаблені. Крім того, запроваджувалися системи планування діяльності 3 метою посилення контролю центру над ефективністю і результативністю надання соціальних послуг на місцях. Такі системи планування у межах окремих програм були запроваджені у Німеччині, Франції та в багатьох інших європейських країнах [5, с. 571-593].

На відміну від західноєвропейських країн, у Східній та Центральній Свропі реформи місцевого самоврядування розпочалися тільки після демократичних революцій, які відбулися тут на рубежі 90-х років. Їхній успіх залежав від зруйнування п'яти могутніх монополій, на яких трималася комуністична система. По-перше, це політична монополія, основою якої була однопартійність влади. Крім неї, слід виділити державну монополію, яка справляла вплив на всі сфери громадського життя. Далі йдуть монополія державної власності та монополія централізованого контролю за громадськими фінансами. I, нарешті, монополія централізованого громадського управління. Хоча загальні мотиви реформування у країнах Центральної та Східної Європи були подібними, самі моделі трансформації та способи їх реалізації суттєво відрізнялися. Це пояснюється історичною специфікою та національними особливостями реформування органів місцевої влади. До названих причин можна додати також бажання посткомуністичних країн звільнитися від шаблонів соціалістичної ери та їхне прагнення запуску ринкових механізмів у сфері муніципальних послуг.

Проблемою, з якою зіткнулися держави на початку перехідного періоду, було розв'язання дилеми: оголосити місцеві вибори негайно, а систему реформувати пізніше, або спочатку запровадити законодавчі зміни, а вже потім оголосити вибори. Перший варіант був бажаним із політичного погляду, оскільки громадськість практично всіх постсоціалістичних країн потребувала негайних кадрових змін, зокрема щодо головних місцевих керівників, які вважалися символами комуністичної влади. Багато країн Центральної та Східної Свропи (окрім Польщі) пішли саме таким шляхом - спочатку вибирали органи місцевої влади, а вже потім бралися за реформування системи. Тому до структур місцевих органів потрапили люди, які не мали ні досвіду, ні знань про функціонування демократичних інститутів. До того ж, у деяких країнах центральні уряди відмовлялися визнавати результати демократичних виборів, намагаючись різними способами обмежити місцеву владу. У Хорватії, наприклад, президент Туджман просто звільнив новообраних мерів, бо вони були представниками опозиційної партії, яка перемогла на місцевих виборах. Тепер, у ретроспективі, зрозуміло, що прийняття альтернативного рішення сприяло б успішній реформі місцевого самоврядування. Це наочно продемонстрував досвід Польщі, яка спочатку змінила законодавство, на основі якого й були побудовані ефективна структура місцевої влади та виборчий процес [6, с. 312-341].

Ще однією проблемою, з якою зіткнулися посткомуністичні країни на шляху трансформаційних змін, стала відмова від принципу однорідності влади у державі. Раніше, під час безроздільного панування тоталітарного режиму, реалізація цього принципу призвела до підпорядкування місцевих та регіональних рад центральним органам влади. В умовах, коли відбувалося запровадження самоврядування, конституційно визначені повноваження мали бути передані від центральних установ до місцевих органів влади. В одних країнах це було зроблено через прийняття відповідних поправок до конституцій (наприклад, у Польщі), в інших, де посткомуністичні партії прагнули легітимності, - через ухвалення нових конституцій (Болгарія, Румунія). Конституційні права місцевої влади були визнані практично в усіх країнах Центральної та Східної Свропи, хоча і з різними обмеженнями. У більшості випадків принцип однорідності влади було скасовано так само, як і державну монополію. Сфера справ місцевого значення була передана 3 юрисдикції центрального уряду до компетенції місцевої влади. Винятком стала Білорусь, де конституція й досі гарантує подвійну роль місцевих та регіональних органів влади [6, с. 357-369].

Після розпаду комуністичної системи і внесення певних змін до законодавства майже всі східноєвропейські держави надали органам місцевого самоврядування, відповідно до їхнього нового статусу, також 
і право володіти державним майном. Проте способи проведення комуналізації та одержані ними права на користування цим майном у кожному конкретному випадку були різними. Основною проблемою тут стало не стільки надання права власності, скільки реальна передача активів місцевій владі.

Важливою сферою, де була проведена демонополізація, стала фінансова. У минулому місцеві бюджети були складовою частиною загальнодержавного бюджету, а використання їх та контроль за ними повністю регулювалися центральною адміністрацією. Децентралізація фіскальної влади в окремих країнах досягла різного рівня. Наприклад, у Польщі місцеві бюджети набули незалежності тоді, коли їх перестали затверджувати у парламенті. Це сталося у 1990 році, ще до проведення місцевих виборів. Передачу фіскальних повноважень згодом було підкріплено новими місцевими джерелами бюджетних надходжень, передусім місцевими податками. Прибуткова частина бюджету гміни (місцева влада у Польщі) складалася 3 державних дотацій (близько $30 \%$ ), частки загальнодержавних податків (22\%) та власних надходжень (30\%). Решта (18\%) бюджету формувалась із різних джерел, таких як позики, облігації, приватизація тощо. Контроль за управлінням муніципальними фінансами було доручено новоствореним регіональним бюджетним службам, де були представлені як центральний уряд та міністерство фінансів, так і місцева влада. Ці нові фіскальні установи, принаймні частково, позбавили центральну адміністрацію ії контрольно-наглядових функцій [6, с. 427-439].

Щодо інших посттоталітарних країн, то типовим явищем для них стало небажання центральної влади ділитися своїми фіскальними повноваженнями. Хоча в багатьох з цих країн були розроблені критерії розрахунку центральних субсидій місцевій владі і тим суттєво обмежено свавілля чиновників центральної адміністрації, однак справжньої фіскальної автономії органи місцевого самоврядування так і не отримали. Навпаки, можна було спостерігати протилежну тенденцію.

Намагаючись поліпшити бюджетну ситуацію, центральний уряд почав делегувати дедалі більше своїх обов'язків місцевій владі, не передаючи при цьому достатніх коштів для їх виконання. Цей феномен добре відомий як «новий федералізм» Рейгана у США, або «тетчеризм» у Великій Британії, внаслідок якого органи місцевої влади змушені були часто виконувати нові для себе обов'язки за рахунок потреб громад. Така примусова передача завдань зверху вниз не лише підірвала довіру суспільства до ідеї самоврядування, а й забезпечила підтримку центральній бюрократії.

Вдалою ілюстрацією цієї тези стала Чехія, де значну частку муніципальних бюджетів становлять субсидії та дотації міністерства фінансів. Така ж ситуація склалася і в Румунії, де субсидії центру фінансують майже 85 відсотків місцевих витрат. Проте $є$ країни, наприклад Македонія, де спостерігається зовсім інша картина: незалежні джерела забезпечують 90 відсотків надходжень до місцевих бюджетів (податки на майно, спадщину та нерухомість, різні збори тощо). Часто місцевій владі не дозволено визначати розміри податків, оскільки це право - прерогатива національних законодавчих органів (Литва, Македонія, Польща, Словенія). У багатьох країнах місцеві уряди просто уповноважені збирати податки, тоді як питаннями визначення розмірів оподаткування займається центральна адміністрація. Отже, аналіз стану самоврядування в країнах Східної та Центральної Свропи засвідчує невисокий рівень децентралізації у фінансовій сфері, набагато нижчий від показників, досягнутих в інших галузях. У кінцевому підсумку це призвело до обмеження можливостей місцевої влади вирішувати локальні питання [7, с. 121-137].

Точкою фокусування децентралізаційних зусиль став також сектор муніципального управління (адміністрації), що аж ніяк не випадково. За комуністичних часів не існувало незалежної місцевої адміністрації. Бюрократія нижчих рівнів була складником апарату загального державного управління. Місцеве керівництво залежало від директорів, правил та щоденних вказівок центральних органів, що виключало будь-яку можливість автономії на місцевому рівні. Реструктуризація системи централізованого управління означала відокремлення національної та місцевих адміністрацій і створення професійних кадрів державних службовців. Наприклад, у Польщі перший крок - відокремлення центральної та місцевих адміністрацій - зроблено у 1990 році, лише після того, як парламент ухвалив закон про службовців місцевого самоврядування. Згідно 3 цим законом прийняття на роботу та звільнення чиновників стало внутрішньою справою муніципалітету, який був захищений від впливу центрального уряду. Та минуло ще 7 років, перш ніж Польща законодавчо вирішила питання про кадри цивільних службовців, тобто професіоналів, незалежних від партійної політики. Працівники місцевого самоврядування у Болгарії й досі мають статус службовців державної адміністрації. У Словенії та Росії закони, що визначають статус службовців органів місцевого самоврядування, все ще перебувають у стадії розроблення [7, с. 153-168].

Нагальною потребою реформованих країн стала підготовка висококваліфікованого персоналу, здатного зрозуміти загальну філософію та нюанси нової структури самоврядування. I знову першою країною, яка швидко відреагувала на цю проблему, була Польща, де вже у 1989 р. діяла загальнонаціональна мережа навчальних центрів, фундацій задля підтримки місцевої демократії. У Чехії, Естонії, Угорщині, Словенії подібні заклади з'явилися наприкінці 90-х років - це були школи місцевого самоврядування, навчальні центри підвищення кваліфікації. Крім того, у названих країнах запроваджено вивчення місцевого самоврядування в університетах. Натомість такі країни, як Литва, Румунія, просто потерпають від недостатньої кваліфікації низькооплачуваних працівників місцевих органів урядування. Повільне становлення прозорої та підзвітної системи муніципальних службовців - серйозна перешкода на шляху розвитку демократичної та ефек- 
тивної структури місцевого самоврядування.

Висновки. Отже, дослідження світової практики процесів децентралізації дало можливість авторам ідентифікувати чотири типи муніципальних реформ: коригування кількості одиниць, організаційні, фінансові та процедурні. Саме реформи місцевого самоврядування стали тим важливим кроком, який започаткував період трансформації принаймні у п'яти сферах: політичній - через запровадження вільних виборів до місцевих органів урядування та відхід від політичної монополії; системній - через конституційні гарантії законодавчої автономії органів місцевого самоврядування; економічній - через перехід від централізованої опору, який усе ще його стримує. системи управління та планування економіки до системи, основою якої є ринок; адміністративній - через скасування керованих із центру рад і делегування певних обов'язків центральної адміністрації органам місцевого самоврядування; громадянській - через створення громадянського суспільства, основою якого $\epsilon$ активна участь громадян у процесах прийняття рішень та вільне вираження своїх поглядів. Подібні зміни Україна також пізнала сповна. Тому вивчення досвіду реформування місцевого самоврядування у розвинених та посттоталітарних країнах, безумовно, допоможе нашій державі глибше збагнути як закономірності цього складного процесу, так і причини того

\section{Список літератури:}

1. Про місцеве самоврядування в Україні: Закон України від 02.10.2018 № 2581-VIII. URL: https:// zakon.rada.gov.ua/ laws/show/280/97 (дата звернення: 17.06.2020).

2. Про добровільне об’єднання територіальних громад: Закон України від 05.02.2015 №157-VIII. URL: https://zakon.rada.gov.ua/laws/show/157 (дата звернення: 17.06.2020).

3. Про співробітництво територіальних громад: Закон України від 17.06.2014 № 1508-VII. URL: https://zakon.rada.gov.ua/ laws/show/1508 (дата звернення: 18.06.2020).

4. Свропейська хартія місцевого самоврядування від 15.10.1985. URL: https:// zakon.rada.gov.ua/laws/show/994_036 (дата звернення: 18.06.2020).

5. Гройсман В.Б. Досвід децентралізації у країнах Свропи. К.: Ін-т законодавства Верховної Ради України, 2015. $766 \mathrm{c}$.

6. Литвин В.М. Акти європейського права $з$ питань регіональної політики та місцевого самоврядування. К.: Парламент. вид-во, 2010. 788 с.

7. Плющ Р.М. Місцеве самоврядування в умовах децентралізації влади в Україні. Київ : Рідна мова, 2016. 744 с.

\section{References:}

1. Pro mistseve samovriaduvannia v Ukraini: Zakon Ukrainy vid 02.10.2018 № 2581-VIII [On local self-government in Ukraine. Law of Ukraine No. 2581-VIII of 02.10.2018]. Available at: https:// zakon.rada.gov.ua/laws/show/280/97 (accessed: 17.06.2020).

2. Pro dobrovilne obiednannia terytorialnykh hromad: Zakon Ukrainy vid 05.02.2015 №157-VIII [On Voluntary Association of Territorial Communities. Law of Ukraine No. №157-VIII of 05.02.2015]. Available at: https://zakon.rada.gov.ua/ laws/show/157 (accessed: 17.06.2020).

3. Pro spivrobitnytstvo terytorialnykh hromad: Zakon Ukrainy vid 17.06.2014 № 1508-VII [On cooperation of territorial communities. Law of Ukraine No. 1508-VII of 17.06.2014]. Available at: https://zakon.rada.gov.ua/laws/show/1508 (accessed: 18.06.2020).

4. Yevropeiska khartiia mistsevoho samovriaduvannia vid 15.10.1985 [European Charter of Local Self-Government of 15.10.1985]. Available at: https://zakon.rada.gov.ua/laws/show/994_036 (accessed: 18.06.2020).

5. Hroisman, V.B. (2015). Dosvid detsentralizatsii u krainakh Yevropy [Experience of decentralization in European countries]. K.: In-t zakonodavstva Verkhovnoi Rady Ukrainy, 766 p.

6. Lytvyn, V.M. (2010). Akty yevropeiskoho prava z pytan rehionalnoi polityky ta mistsevoho samovriaduvannia [Acts of European law on regional policy and local self-government]. K.: Parlament. vyd-vo, 788 p.

7. Pliushch, R.M. (2016). Mistseve samovriaduvannia v umovakh detsentralizatsii vlady v Ukraini [Local self-government in the conditions of decentralization of power in Ukraine]. Kyiv : Ridna mova, 744 p. 


\section{ТИПОЛОГИЗАЦИЯ РЕФОРМ МЕСТНОГО САМОУПРАВЛЕНИЯ}

Мир вступил в эпоху глобального социально-экономического кризиса, которого по масштабам, глубине и продолжительности не было после Великой депрессии. Пандемия как внешний шок парализовала экономику ведущих стран, способствовала их добровольной самоизолячии. В современных кризисных условиях, когда закрываются границы, разорваны хозяйственные связи, отсутствует регулярное сообщение на международном, региональном и национальном уровнях, закономерно возрастает роль местных органов власти и их ответственность за решение проблем самоуправления. Кризис становится катализатором процессов децентрализации и трансформации деятельности местных органов власти. Собственно, эти факторы и обуславливают актуальность выбранной темы, необходимость исследования мировой практики децентрализации и осуществления типологизации муниципальньхх реформ. Использование методов историко-логического и структурно-факторного анализа позволило идентифицировать организационные, финансовые, функциионально-процедурные реформь органов местной власти и корректировки количества территориальных общин.

Ключевые слова: местное самоуправление, типологизация муниципальных реформ, европейская практика децентрализации, территориальные общины, местная автономия.

\section{TYPOLOGIZATION OF LOCAL GOVERNMENT REFORMS}

The methodological and theoretical basis of the study was formed by the fundamental provisions of the European Charter of Local Self-Government in 1985 and the laws of Ukraine - "On Cooperation of Territorial Communities" in 2014, "On Voluntary Association of Territorial Communities" in 2015 and " On Local Self-Government in Ukraine” in 2018. Among the topical issues of decentralization and the main directions of transformational changes are the following: competencies, rights and responsibilities of local governments; taxes and estimates, local finances; economic measures; social infrastructure; utilities; education and medicine; activity of judicial and notarial institutions; work of local administration; local periodicals, statistics and insurance; functioning of mail and ways of communication. In Ukraine, which has chosen the European vector of development, it is also important to define common state standards to which Ukrainian legislation must be brought in order to comply with EU law. It is necessary to comply with the requirements for the level of professional competence of persons. The issues of holding a competition, decent wages, bonuses and material incentives remain fundamentally important.

The world has entered an era of global socio-economic crisis, which in scale, depth and duration was not after the Great Depression. The pandemic, as an external shock, paralyzed the economies of the leading states, contributed to their voluntary self-isolation. In the current crisis, when borders are closed, economic ties are severed, there is no regular communication at the international, regional and national levels, the role of local authorities and their responsibility for solving self-government problems is naturally growing. The crisis is becoming a catalyst for the processes of decentralization and transformation of local government. In fact, these factors determine the relevance of the chosen topic, the need to study the world practice of decentralization and the implementation of the typology of municipal reforms. The use of methods of historical-logical and structural-factor analysis allowed to identify organizational, financial, functionalprocedural reforms of local authorities and to adjust the number of territorial communities.

Key words: local self-government, typology of municipal reforms, European practice of decentralization, territorial communities, local autonomy. 